\title{
INFORMATION AND COMMUNICATION TECHNOLOGIES IN EDUCATION AS A STIMULUS TO ECONOMIC DEVELOPMENT
}

\author{
Rade Stankic*, Biljana Jovanovic Gavrilovic and Jasna Soldic Aleksic \\ Faculty of Economics, University of Belgrade, Belgrade, The Republic of Serbia
}

Education has always been a driving force behind economic prosperity. However, this has become especially important in a globalized knowledge- and new-technology-based economy. The research presented in this paper focuses on the relationship between ICT, population education, and economic growth and development. The analysis of this relationship is based on the latest data collected from relevant national and international institutions. The results obtained from a survey conducted at the Faculty of Economics, University of Belgrade, are also analyzed. The paper highlights the challenges faced by the education systems in general, and the education system of the Republic of Serbia in particular, confronted with the new wave of technological innovation which is fundamentally changing the nature of work and imposing new requirements with regard to the necessary knowledge and skills. Our research results indicate that ICT and education have been recognized by the Government of the Republic of Serbia as the important determinants of economic and the overall social development.

Keywords: information and communication technologies (ICT), education, economic growth, economic development

\section{JEL Classification: 014, M15, L63}

\section{INTRODUCTION}

Information and telecommunication technologies (hereinafter referred to as ICT) are dramatically transforming the world, enabling better connections between people and communities, innovation and productivity increases, as well as improving the global standard of living. While changing the ways

* Correspondence to: R. Stankic, Faculty of Economics, University of Belgrade, Kamenicka 6, 11000 Belgrade, The Republic of Serbia; e-mail: rstankic@ekof.bg.ac.rs people interact and do business, ICTs have been shown to be the key pre-requisite for economic and societal modernization and fostering competitiveness, as well as an important element of overcoming social and economic divides (WEF, 2011, 6).

ICT can be regarded both as a consequence and one of the causes of economic growth, i.e. the strength which acts as a driving force behind economic progress. These technologies contribute to economic growth and foster competitiveness, and they are particularly important to developing countries since they 
accelerate their necessary transformation and allow them to more quickly join the globalization process. ICTs are the key element of economic growth as they contribute to the infrastructure and human potential building and development. However, without skilled labor and the accompanying infrastructure, ICTs alone are an investment loss and only if they complement one another can they generate economic growth. ICTs can also be regarded as a result of economic growth. In developed economies, ICTs are increasingly gaining in significance in an attempt to optimize the rising labor costs.

Why is education essential for economic growth and development? To answer this question, that population education is simultaneously a development instrument and a development goal should be emphasized. On the one hand, education has the key role in enabling a country's economy to absorb new technologies and build a capacity for sustainable growth and development. On the other hand, it is the key development goal and an important dimension of human well-being (Todaro \& Smith, 2011, 359; McCowan, 2016, 506).

Investing in education is investing in human capital, and it is future-oriented. A more narrowly defined concept of human capital includes knowledge and skills, embodied in people through the process of formal education and training, which is in accordance with Becker's minimalist definition of this form of capital (Hanushek \& Woessmann, 2008; Laskowska \& Dańska-Borsiak, 2016). Research has shown that $\$ 1$ invested in knowledge and skills acquisition generates earnings and health benefits of as much as $\$ 10$, depending on the level of a country's economic development (Education Commision, 2017, 35).

The main issue addressed in this paper is the relationship between ICTs, population education, and economic growth and development.

Due to the complexity of this relationship, in addition to the main goal of the paper, which is to examine the effects that the introduction of ICTs in the education system has on economic growth and development, there are also some sub-goals relating to the following relationships: the impact of ICTs on education, the impact of education on economic growth and development, as well as the impact of ICTs on economic growth and development.

In line with the main issue discussed in the paper and its research goals, the following main hypothesis will be tested:

$\mathrm{H} 0$ : In order to create a more effective and more efficient education system, it is necessary to integrate ICTs in all of the aspects of the educational process.

This hypothesis and the research goals set have induced an additional hypothesis:

H1: Efficient operation in the digital working environment increases the interestedness of young people in acquiring new knowledges of and skills for information-communications technologies.

Testing the main hypothesis required a detailed analysis of education development and information society strategies from the global to the national level, whereas in order to test the additional hypothesis, a research study was carried out in the form of a survey conducted among students.

The paper is structured in the three main sections. After certain introductory remarks dealing with the main issue discussed in the paper, the first section focuses on the different projections of the future of education, as well as on education for the future, in the context of sustainable economic development. In the second section, the ways and models of introducing ICTs in the educational process with the aim of preparing workforce for using ICTs in the workplace are analyzed. The focus of the third section is on the Republic of Serbia (RS) and the impact that the application of ICTs in education has on achieving national economic development. In the concluding section, a summary of our research results particularly pointing out the importance of introducing ICTs in education systems with the aim of better preparing the young to operate in the digitized 
workplace and contribute to the macroeconomic and social performances of the country is provided.

\section{THE FUTURE OF EDUCATION AND EDUCATION FOR THE FUTURE IN THE CONTEXT OF (SUSTAINABLE) ECONOMIC DEVELOPMENT}

Education for the future is paid a lot of attention to in development strategies from the national to the global level. At the UN General Assembly in September 2015, the global leaders of 193 UN member states unanimously adopted the 2030 Agenda for Sustainable Development, aimed at achieving steady and high-quality economic development, based on solid economic foundations, environmental responsibility and meeting the criteria for social justice. This is not the present development achieved at the expense of the future one, but the development which meets the needs of the current generations without compromising the future generations' ability to meet their own needs (Mulamula \& AmadiEchendu, 2017, 123). The above-mentioned global agenda for sustainable development encompasses 17 goals, 169 sub-goals and 244 progress-monitoring indicators. From the perspective of this paper, Goal 4 is especially important - to ensure inclusive and equitable quality education and promote lifelong learning opportunities for all, with its sub-goal 4.4. - by 2030, substantially increase the number of youth and adults who have relevant skills, including technical and vocational skills, for employment, decent jobs and entrepreneurship (UN, 2015, 20).

The European Union has recognized the importance of education for the future and its role in achieving sustainable development, which has now been accepted as a universal development model at the level of this regional integration. Consequently, education and training have a prominent place in the EU strategy for the next decade, entitled Europe 2020, which puts forward the following priorities: "Smart growth: developing an economy based on knowledge and innovation. - Sustainable growth: promoting a more resource efficient, greener and more competitive economy. - Inclusive growth: fostering a highemployment economy delivering social and territorial cohesion" (EC, 2010, 8).

In the EU strategies, higher education, research and innovation play the key role in fostering economic growth, global competitiveness and social cohesion. As European societies desire to become knowledgebased, higher education is an essential component of socioeconomic and cultural development. An increasing demand for skills requires higher education to respond to this demand in new ways (EURASHE, 2015, 6).

The Bologna process plays the crucial role in the European higher education development. It is a process of the European higher education reform, aimed at constructing a common area for higher education ("European Higher Education Area, EHEA"). In 2014, the "Bologna Follow-up Group, (BFUG)" adopted the "Standards and Guidelines for Quality Assurance in the European Higher Education Area (ESG)", also adopted by the EHEA Ministers in 2015. The key goal of these standards is to contribute to the common understanding of quality assurance for learning and teaching across borders and among all stakeholders.

Providing broader access to higher education, which is emphasized in the above strategies, is an opportunity for higher education institutions to make use of increasingly diverse student experiences. This diversity and growing expectations for higher education require a fundamental shift in the way it is provided: "a more student-centred approach to learning and teaching, embracing flexible learning paths and recognizing competences gained outside formal curricula. Higher education institutions themselves also become more diverse in their missions, mode of educational provision and cooperation, including growth of internationalization, digital learning and new forms of delivery" (ENQA, 2015).

According to a report of the Education, Audiovisual and Culture Executive Agency (EACEA), in 47 countries of the European Higher Education Area, there are around 37.2 million tertiary students, out 
of whom $82 \%$ are enrolled in theoretically-based programs, whereas only $15.6 \%$ of them are in more occupationally specific programs. Those enrolled in doctoral programs account for $2.6 \%$ of the total student population (EACEA, 2015, 38).

European higher education institutions are predominantly funded by public sources. More than half of the countries spend over $1.3 \%$ of their GDP on higher education, with the Nordic countries spending the most (from $2 \%$ of the GDP in Sweden to $2.4 \%$ of the GDP in Denmark). Annual public expenditure on higher education is the lowest in Bulgaria, Croatia, Italy, Romania and Slovakia, namely below $1 \%$ (EACEA, 2015, 29-31).

The same report states that the number of young adults with tertiary education as a share of the unemployed is very low in Denmark, Great Britain, The Netherlands, whereas Germany is even facing a shortage of such people. On the other hand, young adults with tertiary education in Bosnia and Herzegovina, Greece, Croatia, Cyprus, Portugal, Romania and Serbia are being faced with a high unemployment rate.

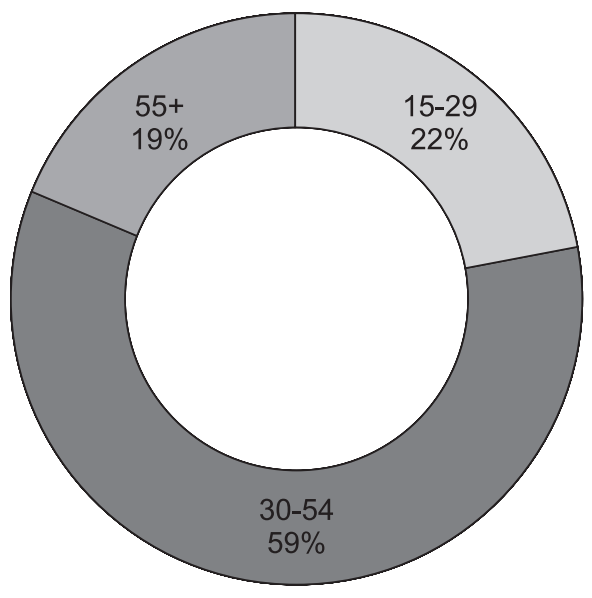

Figure 1 The share of the unemployed by age group in the total number of the unemployed, 2017

Source: Nacionalna služba za zapošljavanje (RSZ DevInfo, 2018, 3).

According to data obtained from the Statistical Office of the Republic of Serbia and the National
Employment Agency, young adults in RS aged 1529 account for $22 \%$ of the total number of people unemployed (Figure 1). Unemployment is one of the reasons for leaving the country by young adults and especially increased talent outflows.

In line with the need to adapt its education system to modern requirements and in accordance with the strategies approved of in a wider context, especially in the EU area, the Government of Serbia adopted the Strategy for Education Development in Serbia 2020. The Strategy deals with establishing goals, objectives, directions, tools and mechanisms for the development of the education system in the Republic of Serbia until 2020. The Strategy particularly emphasizes the following development goals (Vlada RS, 2012):

- directing the structure of educational and research activities towards meeting the developmental needs of the economy and society;

- increasing the share of population with tertiary education in the total population;

- directing the financing system towards the formation of creative, innovative, responsible people with tertiary education necessary for the achievement of economic growth and reducing unemployment.

\section{INFORMATION AND COMMUNICATION TECHNOLOGIES IN EDUCATION}

ICTs require different knowledge and skills in order to fully exploit their power both in private and professional settings. This relationship may be viewed from the two perspectives: firstly, ICTs are required for the improvement of the teaching and learning process, and secondly, there is a need to learn through the education process how to make the best use of these technologies in various areas of human activities, including business.

The use of ICTs makes the education process go beyond the traditional instruction and the barriers of time and the location, which is why it is often referred to as e-education. 
The term e-education is most frequently defined as educational activities conducted by using ICTs or as electronically assisted learning. E-education has the following goals: independent and permanent learning, improving instructional efficacy, the flexible organization of instructions and the inclusion of a larger number of people willing and able to learn in the instruction process.

Some of the benefits of e-education are the following: the ability to access the instruction process at any time or place; a better teacher-student interaction; time saving; an improved efficiency; flexible learning; an individual approach to students and respecting different learning styles; the adjustment of content and the pace of learning to individual students (adaptive learning); fostering analytical thinking and independent problem-solving skills in students; synthetizing the acquired knowledge; the easy monitoring of student progress; easier training and retraining; offering new opportunities for lifelong learning; easy access to lectures by world-renowned experts by means of video-conferencing; a greater learner diversity (the employed, students from remote areas, mobility-impaired students, etc.).

Some of the modern technologies used in e-education are as follows: smart learning environments, the Internet of things, a virtual learning environment, virtual reality technologies, mobile technologies, etc.

Another dimension to learning has been added by Virtual Learning Environment (VLE), a web-based system which creates an environment designed to facilitate the learning course management. The VLE also includes distance learning.

Also used in education are new technologies such as IoT (Internet of Things) and Cloud Computing, which create Smart Learning Environments. The Internet of things (IoT) is a concept which expands the virtual world and the Internet to real-world physical things, thus enabling resource virtualization. Cloud Computing is a technology that enables interaction between users and different services available on the Internet.

The power of Virtual Reality (VR) technologies is particularly manifested in opportunities for learning by experience through conducting experiments which can teach students how to solve complex problems in the ways different from traditional teaching methods.

The use of mobile technologies in education is another way of learning transformation. Mobile technologies can significantly impact the development of the learning environment.

Respecting the needs of the EU education systems, in its document Opening up Education: Innovative Teaching and Learning for all through New Technologies and Open Educational Resources, the European Commission points out that technologies and open educational resources offer an opportunity to reshape education (EC, 2013).

This document sets out an agenda for stimulating the high-quality, innovative ways of learning and teaching through new technologies and digital content. Opening up Education proposes actions towards creating more open learning environments to ensure the education of a higher quality and efficacy, thus contributing to the Europe 2020 Strategy's goals, predominantly related to boosting the EU competitiveness through better skilled workforce and increased employment. The main goals are reducing early school leavers and increasing the number of people with tertiary education. The document also proposes actions at the EU level: helping learning institutions, teachers and learners to acquire digital skills and learning methods; supporting the development and availability of open educational resources; deploying digital devices and content in the classroom; mobilizing all stakeholders (teachers, pupils and students, families, companies and social partners) in order to change the role of digital technologies at educational institutions (EC, 2013).

New technologies in higher education contribute to creating the workforce necessary for a significant economic impact on the ICT sector development (Kvochko, 2013): the GDP growth; the emergence of new services and industries; business innovation; workforce transformation; job creation. This is why the document Strategy for Education Development in Serbia 2020 sets the following as one of its goals the harmonization of academic study programs with 
the needs of the economy, as well as cooperation in the implementation of the practical training of students, so that students at university acquire more knowledge, skills and competences that are relevant to employers' needs (Vlada RS, 2012).

The Strategy for Education Development in Serbia 2020 emphasizes the importance of digital technologies for the overall development of the education system. However, the first official document which thoroughly deals with the integration of digital and online learning in education was adopted by the National Education Council of the Republic of Serbia in 2013 and presented to the public - Guidelines to Improve ICT in Education.

\section{ICT IN EDUCATION AS A STIMULUS TO SERBIAN ECONOMIC GROWTH AND DEVELOPMENT}

ICTs have for many years now been a central issue in debates about economic growth and the functioning of developed, and also of undeveloped and developing economies.

The deployment of ICTs in education and raising the level of the knowledge and skills necessary for using new technologies by the wide population have been recognized by the Government as a significant driving force behind the development of the Serbian economy and society.

The most important goals of the fuller implementation of ICTs in education in Serbia have been put forward in the Information Society Development Strategy in the Republic of Serbia 2020. These goals are the following: establishing a modern education system adapted to the needs of information society; enabling the use of ICTs in the workplace in a way which raises the level of efficiency, improves work quality and ensures better jobs; and introducing the concepts of e-learning and open distance learning.

To meet the social and economic objectives, competencies are required. These competencies are acquired by reforming the education sector in such a way as to create preconditions for building a knowledge economy and stimulating ICT training programs. Consequently, changes need to be made in education in order to modernize the learning process and encourage creativity and innovation. The connection between the ICT sector and education will help young people to acquire the skills necessary for the digital work environment.

The current state of the Serbian ICT sector is presented in the below analysis.

According to the data obtained from the Statistical Office of the Republic of RS (SORS), and the Chamber of Commerce and Industry of RS (CCIS), in 2015, there were 3,401 enterprises operating in the RS ICT sector, accounting for $3.7 \%$ of the total number of the registered enterprises in the Republic of Serbia. Out of this number, the most registered enterprises operate in the field of computer programming $(54.9 \%)$, then computer, electronic and optical products manufacture $(26.8 \%)$, only to be followed by telecommunications $(11.5 \%)$.

As can be seen in Table 1, the micro- and small-sized enterprises accounted for $97.0 \%$ of the total number of the registered enterprises, whereas the highest turnover was generated by the largest enterprises. It can also be seen that the number of the employees is the highest in large and medium-sized enterprises (Table 1).

Table 1 The structure of the enterprises in the electronic communications and information society sector - 2015

\begin{tabular}{c|cccccc}
\hline & Total & $\begin{array}{c}\text { Micro } \\
1-9\end{array}$ & $\begin{array}{c}\text { Small } \\
10-49\end{array}$ & $\begin{array}{c}\text { Medium } \\
50-249\end{array}$ & $\begin{array}{c}\text { Large } \\
250+\end{array}$ \\
\hline Enterprises & 3,401 & $85.6 \%$ & 11.4 & 2.4 & 0.6 \\
Employees & 55,159 & $10.5 \%$ & 14.1 & 15.5 & 59.8 \\
$\begin{array}{c}\text { Turnover } \\
\text { (in RSD bn) }\end{array}$ & 418.9 & $7.8 \%$ & 14.2 & 21.4 & 56.6 \\
\hline
\end{tabular}

Source: RSZ and APR, calculation based on the PKS data. 
In 2016, the ICT sector in RS employed 61,077 persons, which was a rise of $2.5 \%$ compared to 2015. A significant increase (23.9\%) in the number of employees relative to the period January-December 2015 was recorded in computer programming, consulting and related activities (PKS, 2017).

In the period January-March 2017, the highest gross salary paid in the ICT sector was RSD 205,259 in computer programming, consulting and related activities, which is about three times higher than the Republic average (RSD 62,588) (PKS, 2017).

According to the RSZ and PKS data (PKS, 2017), the year 2015 recorded a positive contribution of all ICT sectoral activities to the interannual growth of the GDP. A significant interannual growth of gross value added was recorded in computer programming and consulting activities (25.3\%) and information services (27.9). The gross value added created in computer programming, consulting and related activities in 2015 totaled EUR 402.2 mil. The total fixed assets investment in all of the IT-related activities was EUR 476.8 mil in 2015, of which the largest share (EUR 225.3 mil) was invested in domestic and imported equipment $(47.3 \%)$, while $41.8 \%$ was invested in intellectual property (research and development, software, databases, etc.) - EUR 199.2 mil. In computer programming, consulting and related activities, almost $69.2 \%$ of the total investment accounted for those made in research and development, software and databases.

According to the RSZ and PKS data (PKS, 2017), in industries comprising electronic communications and information society in 2016, there was a foreign direct investment net inflow by non-residents in the amount of EUR 100.2 mil. In the three-year period between 2014 and 2016, there was an average annual rise in the foreign direct investment net inflow of $70.1 \%$.

According to the NBS and PKS data (PKS, 2017), Serbian telecommunications, computer and information services exports in 2016 totaled EUR 739.5 mil. In the four-year period 2013-2016, these exports rose at an average annual rate of $19.2 \%$. There was a trade surplus of these services worth EUR 407.3 mil. In the four-year period 2013-2016, the trade surplus in these services increased at an average annual rate of $36.9 \%$, with the largest surplus recorded in trade in computing services (43.2\%).

Based on the data presented, a conclusion can be drawn that the ICT sector in RS, although accounting for $3.7 \%$ of the total number of the registered enterprises and $3.2 \%$ of the total number of the employed in our country, recorded exports worth EUR 739.5 in 2016, with a trade surplus in the services in the ICT sector worth EUR 407.3 mil. In addition, in RS, a country characterized by high unemployment, IT-related positions are among the rare ones where demand exceeds supply.

At the global level, the ICT sector is one of the fastestgrowing industries, which directly impacts job creation and encourages the development of the other sectors of the economy. In order to be competitive on the global market, modern companies need to use the latest technologies, simultaneously keeping their costs at a low level. This has resulted in the transfer of such technologies from the economically most developed countries to India, China and other Asian countries with cheap and skilled workforce. These trends are now affecting RS as well, as a country which has an insufficient number of the highly educated people capable of using ICTs in business (Bartlett, 2009, 33).

As can be seen from the above analysis, computer programming and providing a variety of information services are becoming the increasingly important factors of the Serbian economic development. ITrelated occupations are the most in-demand in the labor market. Therefore, the Serbian IT industry is offering important opportunities to young talents and highly educated people to develop their careers in the country and be satisfied with their social status and a chance to contribute to the country's prosperity. However, there are important shortcomings of the Serbian ICT industry: a large number of microenterprises with a low financial capacity and insufficient technological and managerial skills, as well as a shortage of skilled labor.

Yet another shortcoming should be mentioned here: the fact that we are not capable of retaining talents in the country, because, according to the World 
Economic Forum data showing a country's capacity to retain talents, RS ranks the $134^{\text {th }}$ of 137 countries (WEF, 2017, 257).

However, we should bear in mind the fact that the conclusion that investment in education is worthwhile and that it will result in an accelerated economic growth is only valid under the assumption that people will be given jobs and thus simultaneously an opportunity to contribute to economic development. The positive experience of some countries indicates that, instead of directing the whole economy, it is much better for countries to focus on the sectors capable of ensuring progress, such as the ICT sector in Serbia. Consequently, this entails the need for adjusting the education system accordingly.

\section{FORMAL IT EDUCATION IN THE REPUBLIC OF SERBIA}

In primary school grades $1-4$, there is an optional subject entitled From Toys to Computers. In September 2015, Informatics and Computer Programming was introduced in primary school grade 5 as a compulsory subject. This subject will also be a part of the curricula of primary school grades 6-8.

In high school grades 1-4, as well as in secondary vocational school grade 1, Informatics and Computer Programming is taught as a compulsory subject. In secondary vocational school grades 2-4, the informatics-related subjects have been adjusted to a particular field. Thus, for example, Business Informatics is taught in vocational schools offering the economics, law and administration programs.

Technical faculties and faculties of mathematics lie at the core of ICT tertiary education, research and development. These faculties focus on engineering informatics, whereas the study programs in business informatics are still scarce.

The fact that study programs in the field of business informatics, particularly at state-owned faculties, are still scarce is mainly due to the fact that informatics engineers in RS are recognized as IT experts, while business informatics professionals have not been sufficiently established yet. Nevertheless, commendable changes have been made in this respect, mainly being manifested through precisely defining the skills and knowledge deemed essential by the employer in the field of business informatics. Namely, a business component in informatics is increasingly in demand, which can be concluded on the basis of job advertisements posted on poslovi.infostud, one of the leading job search websites in Serbia. Out of the total number of the IT jobs offered (around 300), approximately 200 are those requiring competencies both in the ICT and a particular business areas that students are supposed to have upon graduation (INFOSTUD, 2018).

Currently, Serbia's labor market is faced with a shortage of informatics experts oriented towards the use of information technology in business, developing business software, IT project management and the business information system development. The factors that have contributed to such increased demand for these occupations are as follows:

- the number of domestic and in particular international IT companies dealing with business software development has significantly increased in the last several years in RS, which offers IT professionals an opportunity to work from RS for companies worldwide;

- quality university programs in the area of business informatics could significantly improve the Serbian software industry;

- an increased interest in the university courses providing the knowledge and skills that integrate economics with information technology and offer good job opportunities after graduation.

Based on the data about the Serbian labor market's needs presented in this paper and aiming at obtaining more information about the students' interest in the subjects liaising ICT and economics, a survey was conducted among 535 students at the Faculty of Economics, Belgrade University. The survey contained a large number of questions, but for the purposes of 
this paper, only the questions referring to the subjects connecting ICT and economics were selected.

The analysis of the students' interest in the subjects oriented towards the use of ICT business, included in the Business Informatics Module (Business Informatics, Databases, Data Analysis, Object-Oriented Programming, Mathematics for Programming, Web Design, Information Systems and Business Analytics, E-Business, Software Development, IT Project Management, ERP Software, New Information Technologies, E-Commerce, E-Payment Systems. Digital Marketing and Accounting Information Systems), indicate that the students are particularly interested in the following subjects: Digital Marketing - $63.6 \%$ of the students surveyed, E-Commerce - 60.9\%, Web Design - 60\%, E-Business - 54.9\%, IT Project Management - 51.6\%, E-Payment Systems - 49.6\%, New Information Technologies - $47.1 \%$ of the students surveyed. The details of the students' interest in these subjects are accounted for in Tables 2-8 below.

Table 2 The level of the students' interest in Web Design

\begin{tabular}{|c|c|c|c|c|c|}
\hline & & No & $\%$ & $\begin{array}{l}\% \text { of valid } \\
\text { responses }\end{array}$ & $\begin{array}{l}\% \text { of } \\
\text { total }\end{array}$ \\
\hline \multirow{6}{*}{ 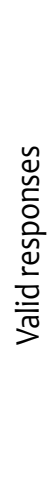 } & Not interested & 45 & 8.4 & 8.6 & 8.6 \\
\hline & $\begin{array}{l}\text { Somewhat } \\
\text { interested }\end{array}$ & 50 & 9.3 & 9.6 & 18.2 \\
\hline & $\begin{array}{l}\text { Moderately } \\
\text { interested }\end{array}$ & 106 & 19.8 & 20.3 & 38.5 \\
\hline & Interested & 130 & 24.3 & 24.9 & 63.4 \\
\hline & Very interested & 191 & 35.7 & 36.6 & 100.0 \\
\hline & Total & 522 & 97.6 & 100.0 & \\
\hline & Missing data & 13 & 2.4 & & \\
\hline & Total & 535 & 100.0 & & \\
\hline
\end{tabular}

Source: Authors
Table 3 The level of the students' interest in E-Business

\begin{tabular}{|c|c|c|c|c|c|}
\hline & & No & $\%$ & $\begin{array}{l}\% \text { of valid } \\
\text { responses }\end{array}$ & $\begin{array}{l}\% \text { of } \\
\text { total }\end{array}$ \\
\hline & Not interested & 39 & $7 \cdot 3$ & 7.4 & 7.4 \\
\hline & $\begin{array}{l}\text { Somewhat } \\
\text { interested }\end{array}$ & 53 & 9.9 & 10.1 & 17.5 \\
\hline 气ั & $\begin{array}{l}\text { Moderately } \\
\text { interested }\end{array}$ & 139 & 26.0 & 26.5 & 44.0 \\
\hline 믐 & Interested & 158 & 29.5 & 30.1 & 74.1 \\
\hline & Very interested & 136 & 25.4 & 25.9 & 100.0 \\
\hline & Total & 525 & 98.1 & 100.0 & \\
\hline & Missing data & 10 & 1.9 & & \\
\hline & Total & 535 & 100.0 & & \\
\hline
\end{tabular}

Source: Authors

Table 4 The level of the students' interest in ObjectOriented Programming

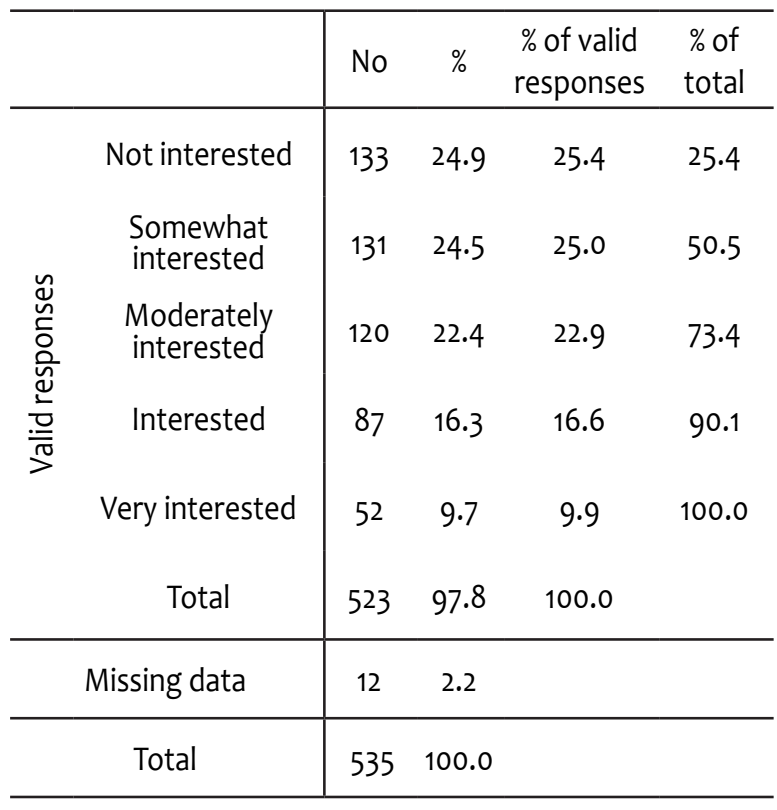

Source: Authors 
Table 5 The level of the students' interest in Software Development

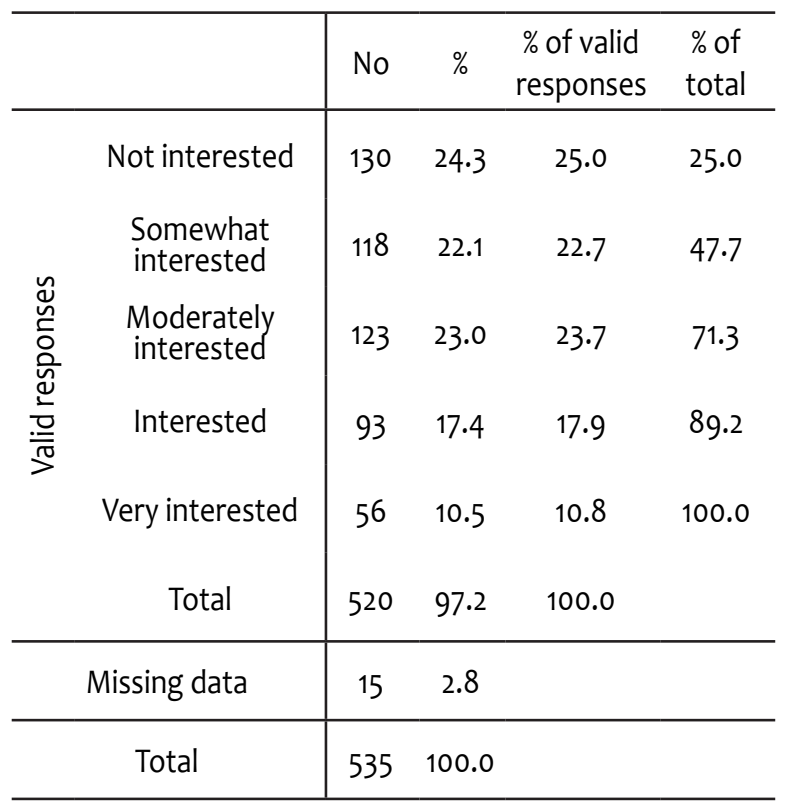

Source: Authors

Table 6 The level of the students' interest in New Information Technologies

\begin{tabular}{|c|c|c|c|c|c|}
\hline & & No & $\%$ & $\begin{array}{l}\% \text { of valid } \\
\text { responses }\end{array}$ & $\begin{array}{l}\% \text { of } \\
\text { total }\end{array}$ \\
\hline \multirow{6}{*}{ 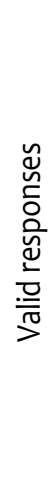 } & Not interested & 55 & 10.3 & 10.6 & 10.6 \\
\hline & $\begin{array}{l}\text { Somewhat } \\
\text { interested }\end{array}$ & 94 & 17.6 & 18.1 & 28.7 \\
\hline & $\begin{array}{l}\text { Moderately } \\
\text { interested }\end{array}$ & 119 & 22.2 & 22.9 & 51.5 \\
\hline & Interested & 131 & 24.5 & 25.2 & 76.7 \\
\hline & Very interested & 121 & 22.6 & 23.3 & 100.0 \\
\hline & Total & 520 & 97.2 & 100.0 & \\
\hline & Missing data & 15 & 2.8 & & \\
\hline & Total & 535 & 100.0 & & \\
\hline
\end{tabular}

Source: Authors
Table 7 The level of the students' interest in E-Commerce

\begin{tabular}{|c|c|c|c|c|c|}
\hline & & No & $\%$ & $\begin{array}{l}\% \text { of valid } \\
\text { responses }\end{array}$ & $\begin{array}{l}\% \text { of } \\
\text { total }\end{array}$ \\
\hline & Not interested & 31 & 5.8 & 5.9 & 5.9 \\
\hline & $\begin{array}{l}\text { Somewhat } \\
\text { interested }\end{array}$ & 49 & 9.2 & 9.4 & $15 \cdot 3$ \\
\hline 气̆ & $\begin{array}{l}\text { Moderately } \\
\text { interested }\end{array}$ & 118 & 22.1 & 22.5 & 37.8 \\
\hline 음 & Interested & 161 & 30.1 & 30.7 & 68.5 \\
\hline & Very interested & 165 & 30.8 & 31.5 & 100.0 \\
\hline & Total & 524 & 97.9 & 100.0 & \\
\hline & Missing data & 11 & 2.1 & & \\
\hline & Total & 535 & 100.0 & & \\
\hline
\end{tabular}

Source: Authors

Table 8 The level of the students' interest in Digital Marketing

\begin{tabular}{|c|c|c|c|c|c|}
\hline & & No & $\%$ & $\begin{array}{l}\% \text { of valid } \\
\text { responses }\end{array}$ & $\begin{array}{l}\% \text { of } \\
\text { total }\end{array}$ \\
\hline \multirow{8}{*}{ 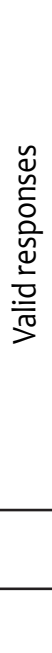 } & Not interested & 33 & 6.2 & 6.3 & 6.3 \\
\hline & $\begin{array}{l}\text { Somewhat } \\
\text { interested }\end{array}$ & 48 & 9.0 & 9.2 & 15.5 \\
\hline & $\begin{array}{l}\text { Moderately } \\
\text { interested }\end{array}$ & 102 & 19.1 & 19.5 & 35.0 \\
\hline & Interested & 138 & 25.8 & 26.4 & 61.4 \\
\hline & Very interested & 202 & 37.8 & 38.6 & 100.0 \\
\hline & Total & 523 & 97.8 & 100.0 & \\
\hline & Missing data & 12 & 2.2 & & \\
\hline & Total & 535 & 100.0 & & \\
\hline
\end{tabular}

Source: Authors 
As the survey results indicate, the students are especially interested in the business-oriented informatics subjects, i.e. the subjects focusing on the use of ICTs in a particular business area.

\section{CONCLUSION}

This paper points out the key role of the high-quality inclusive education necessary for achieving dynamic and sustainable development and defining a desirable direction of change in line with the demands of the new age.

Investing in education is investing in the future. A strong impact of new technologies on education and the world of work is a global trend. These changes are manifested by the emergence of new job and occupation categories, which will partially or entirely replace the existing jobs. The required knowledge and skills will also significantly change. It is essential to promptly deal with the challenges of the new age in order to avoid enormous economic and social costs imposed on individuals, companies and the economy. The paper points out that the new wave of technological change offers tremendous opportunities to countries across the globe, including those less-developed, to significantly enhance their economic and social performances by transforming their education systems. In this context, education is recognized as a development opportunity for the Republic of Serbia. This is corroborated by our research results, as well as by the necessity for change, ranging from the way education is treated in the society, via the reforms in the education system itself, to the construction of relevant economic, legal and political institutions so as to motivate young people to acquire knowledge and thus increase the country's capacity to retain and attract the most qualified workforce.

The paper also stresses the necessity to integrate new technologies in all of the aspects of the education process, with the goal of providing more efficient and more effective education. New technology skills are decisive for the global competitiveness of the national economy and the maximizing of the job-creating potential.

In addition, changes need to be introduced in schools, universities and other educational institutions in order to modernize the learning process and encourage students' innovation and creativity by fully exploiting the opportunities provided by new technologies. The introduction of new technologies in education should enable young adults with tertiary education, equipped with the adequate knowledge and skills and capable of using cutting-edge technology, to contribute to the development of their country's economy.

This paper contributes to the scarce literature on the indirect effects that the application of ICTs in education has on economic growth and development as these effects have not been researched extensively and in their entire complexity.

The systematic analysis of education and information society development strategies conducted in this paper from the global level (UN) and the EU level to the level of RS and the particular curriculum applied the Faculty of Economics of the University of Belgrade has confirmed our basic hypothesis: in order to create a more effective and more efficient education system, it is necessary that ICTs should be integrated in all the aspects of the educational process.

The detailed analysis of the ICT sector and the labor market in Serbia based on the data obtained from the relevant institutions (NSZ, NBS, PKS, NEA, etc.), as well as the survey data, has confirmed our additional hypothesis referring to the increased interest of young adults in acquiring the ICT-related knowledge and skills necessary for their efficient working in a digitized workplace, which will enable them to contribute to the country's economic growth and development.

The research study conducted and presented in this paper provides the answer to the question of how the application of ICTs in education fosters economic growth and development. However, one open question still remains, relevant for further studies, which refers to measuring the extent to which the use of ICTs in education fosters economic growth 
and development. Additionally, a more precise analysis of the students' interest in applying ICTs in the economy would benefit from a broader and more comprehensive survey designed after that conducted at the Faculty of Economics, Belgrade University, encompassing several higher-level educational institutions in the Republic of Serbia.

\section{ACKNOWLEDGEMENT}

This paper is part of the research projects no. 179005, 179065 and III-46001, funded by the Ministry of Education, Science and Technological Development of the Republic of Serbia.

\section{REFERENCES}

Bartlett, W. (2009). Economic development in the European super-periphery: Evidence from the Western Balkans. Economic Annals, 64(181), 21-44. doi:10.2298/EKA0981021B

EACEA (Education, Audiovisual and Culture Executive Agency). (2015). The European Higher Education Area in 2015. Brussels, Belgium.

EC - European Commission. (2010). Europe 2020 - A Strategy for smart, sustainable and inclusive growth. Brussels: $\operatorname{COM}(2010)$ 2020 final. Retrieved March 24, 2018, from ec.europa.eu/ eu2020/pdf

EC - European Commission. (2013). Opening up Education: Innovative teaching and learning for all through new Technologies and Open Educational Resources. Brussels, Belgium.

EC - European Commission. (2014). Digital Agenda for Europe. Brussels, Belgium.

EC - European Commission. (2016). A New Skills Agenda for Europe. Brussels, Belgium.

EC - European Commission. (2017). National Student Fee and Support Systems in European Higher Education, 2017/18. Brussels, Belgium.

Education Commission. (2017). The Learning Generation - Investing in education for a changing world. Retrieved December 13, 2017, from report.educationcommission.org
ENQA - European Association for Quality Assurance in Higher Education. (2015). Standards and Guidelines for Quality Assurance in the European Higher Education Area. Brussels, Belgium.

EURASHE - European Association of Institutions in Higher Education. (2015). Standards and Guidelines for Quality Assurance in the European Higher Education Area (ESG). Brussels, Belgium.

Hanushek, E., \& Woessmann, L. (2008). The role of cognitive skills in economic development. Journal of Economic Literature, 46(3), 607-678. doi:10.1257/jel.46.3.607

Infostud. (2018). Poslovi Infostud.

Kvochko, E. (2013). Five ways technology can help the economy. World Economic Forum.

Laskowska, I., \& Dańska-Borsiak, B. (2016). The Importance of human capital for the economic development of EU regions. Comparative Economic Research, 19(5): 63-79. doi. org/10.1515/cer-2016-0038

McCowan, T. (2016). Universities and the post-2015 development agenda: An analytical framework. Higher Education, 72(4), 505-523. doi:10.1007/s10734-016-0035-7

Mulamula, G., \& Amadi-Echendu, J. (2017). An examination of the potential links between ICT technology transfer and sustainable development. International Journal of Technology Management \& Sustainable Development, 16(2), 119-139. doi:10.1386/tmsd.16.2.119_1

NPS - Nacionalni prosvetni savet Srbije. (2013). Smernice za unapređenje uloge informaciono-komunikacionih tehnologija $u$ poslovanju.

PKS - Privredna komora Srbije. (2017). Bilten, april 2017. Udruženje za elektronske komunikacije i informaciono društvo.

RZS - Republički zavod za statistiku DevInfo. (2018) Republika Srbija - profil. Retrieved March 11, 2018, from http://devinfo. stat.gov.rs

Schwab, K. (2016). Fourth Industrial Revolution. Geneva, Svis: World Economic Forum.

Vlada Republike Srbije. (2010). Strategija razvoja informacionog društva u Srbiji do 2020. godine. Službeni glasnik RS, br. 51/2010.

Vlada Republike Srbije. (2012). Strategija razvoja obrazovanja u Srbiji do 2020. godine. Službeni glasnik RS, br. 107/2012.

Todaro, M. P., \& Smith, C. S. (2011). Economic Development. Harlow: Addison-Wesley. 
UN. (2012). The Future We Want. Geneva, United Nations: Retrieved March 14, 2018, from http:// sustainabledevelopment.un.org/content/documents/ 733FutureWeWant.pdf

UN. (2015). Transforming Our World: the 2030 Agenda for Sustainable Development. Geneva: United Nations.
UNESCO. (2016). Global Education Monitoring Report - Education for People and Planet: Creating Sustainable Futures for All. Paris, France: UNESCO.

WEF - World Economic Forum. (2011). The Global Information Technology Report 2010-2011.

WEF - World Economic Forum. (2017). The Global Information Technology Report 2016.

$$
\begin{array}{r}
\text { Received on } 16^{\text {th }} \text { March } 2018, \\
\text { after revision, } \\
\text { accepted for publication on } 23^{\text {rd }} \text { April } 2018 . \\
\text { Published online on } 26^{\text {th }} \text { April } 2018 .
\end{array}
$$

Rade Stankic is a full professor at the Faculty of Economics, Belgrade University. His research interests focus on the area of business informatics and business information systems.

Biljana Jovanovic Gavrilovic is a full professor at the Faculty of Economics, Belgrade University. Her research interests encompass the issues relating to the national economy.

Jasna Soldic Aleksic is a full professor at the Faculty of Economics, Belgrade University. Her research interests focus on the issues relating to data analysis and business information systems. 


\title{
INFORMACIONO-KOMUNIKACIONE TEHNOLOGIJE U OBRAZOVANJU KAO PODSTICAJ EKONOMSKOM RAZVOJU
}

\author{
Rade Stankić*, Biljana Jovanović Gavrilović i Jasna Soldić Aleksić \\ Ekonomski fakultet Univerziteta u Beogradu
}

\begin{abstract}
Obrazovanje je oduvek bilo pokretačka snaga ekonomskog prosperiteta, a u globalizovanoj privredi zasnovanoj na znanju i na primeni novih tehnologija to posebno dolazi do izražaja. U fokusu istraživanja predstavljenih u ovom radu su međusobni odnosi informaciono-komunikacionih tehnologija (IKT), obrazovanja stanovništva i ekonomskog rasta i razvoja. Za analizu tih odnosa korišćeni su podaci relevantnih domaćih i međunarodnih institucija. Posebno su analizirani podaci iz ankete koju su autori sproveli na Ekonomskom fakultetu Univerziteta u Beogradu. U radu su apostrofirani izazovi sa kojima se suočavaju obrazovni sistemi širom sveta, a posebno obrazovni sistem Republike Srbije, pred novim talasom tehnoloških inovacija, koji iz temelja menja samu prirodu procesa rada i postavlja nove zahteve kada je reč o neophodnim znanjima i veštinama. Rezultati istraživanja pokazuju da su IKT i obrazovanje prepoznati od strane države Republike Srbije kao značajne determinante ekonomskog i ukupnog društvenog razvoja.
\end{abstract}

Ključne reči: informaciono-komunikacione tehnologije (IKT), obrazovanje, ekonomski rast, ekonomski razvoj

JEL Classification: 014, M15, L63

\section{UVOD}

Informaciono-komunikacione tehnologije (IKT) dramatično menjaju svet, omogućavajući bolje veze između ljudi i zajednica, inovacije i rast produktivnosti, kao i povećanje životnog standarda stanovništva na globalnom nivou. Uporedo sa promenom međuljudske interakcije i poslovanja, IKT

* Korespondencija: R. Stankić, Ekonomski fakultet Univerziteta u Beogradu, Kamenička 6, 11000 Beograd, Republika Srbija; e-mail: rstankic@ekof.bg.ac.rs su se pokazale i kao ključni preduslov za ekonomsku i društvenu modernizaciju, jačanje konkurentnosti, ali i kao bitan element u cilju prevazilaženja društvenih i ekonomskih podela (WEF, 2011, 6).

IKT se mogu posmatrati i kao posledica, ali i kao jedan od uzročnika ekonomskog razvoja, odnosno snaga koja pokreće privredni progres. Ove tehnologije doprinose unapređenju konkurentnosti i ekonomskom rastu, a poseban značaj imaju za zemlje u razvoju, jer ih ubrzano uvode $u$ neophodnu transformaciju i 
proces globalizacije. IKT predstavljaju bitan element ekonomskog rasta, jer doprinose izgradnji i razvoju infrastrukture i ljudskog potencijala. Međutim, samo postojanje IKT bez kvalifikovanih ljudskih resursa i prateće infrastrukture predstavlja investicioni gubitak, a jedino u njihovom komplementarnom sadejstvu generišu ekonomski rast. IKT se mogu shvatiti i kao rezultat ekonomskog rasta. U razvijenim privredama, IKT dobijaju značajnu ulogu u nastojanjima da se izvrši optimizacija rastućih troškova ljudskih resusrsa.

Zašto je obrazovanje uopšte važno za ekonomski rast i razvoj? U odgovoru na to pitanje, pre svega treba naglasiti, da se obrazovanje stanovništva u isto vreme javlja i kao sredstvo i kao cilj razvoja. S jedne strane, obrazovanje igra ključnu ulogu u unapređivanju sposobnosti ekonomije zemlje da apsorbuje modernu tehnologiju i izgradi kapacitet za održivi rast i razvoj, a, s druge strane, predstavlja osnovni cilj razvoja i važnu dimenziju ljudskog blagostanja (Todaro \& Smith, 2011, 359; McCowan, 2016, 506).

Ulaganja u obrazovanje imaju karakter investicija u ljudski kapital i okrenuta su ka budućnosti. Uže shvatanje ljudskog kapitala uključuje znanje i umeće, opredmećeno u ljudima kroz proces formalnog obrazovanja i obuke, što je kompatibilno sa Beckerovom minimalističkom definicijom ove forme kapitala (Hanushek \& Woessmann, 2008; Laskowska \& Dańska-Borsiak, 2016). Istraživanja pokazuju da $1 \$$ uložen u sticanje znanja i veština donosi koristi u domenu zarada i zdravlja do, čak, 10\$ u zavisnosti od dostignutog nivoa ekonomske razvijenosti zemlje (Education Commision, 2017, 35).

Predmet ovog rada su međusobni odnosi IKT, obrazovanja i ekonomskog rasta i razvoja.

Pošto su ti odnosi kompleksni, pored glavnog cilja rada, koji se odnosi na sagledavanje uticaja uvođenja IKT u obrazovni sistem na ekonomski rast i razvoj, postavljeni su i podciljevi koji se odnose na razmatranje sledećih odnosa: uticaj IKT na obrazovanje; obrazovanja na ekonomski rast i razvoj; kao i uticaj IKT na ekonomski rast i razvoj.

Shodno postavljenom predmetu i ciljevima istraživanja, u radu je testirana osnovna hipoteza:
H0: Za potrebe efektivnijeg i efikasnijeg obrazovanja neophodno je integrisanje IKT u sve aspekte obrazovnog procesa.

Ova hipoteza i postavljeni ciljevi istraživanja indukovali su dodatnu hipotezu:

H1: Efikasno funkcionisanje $u$ digitalnom radnom okruženju povećava zainteresovanost mladih ljudi za sticanje novih znanja i veština iz informaciono-komunikacionih tehnologija.

Testiranje osnovne hipoteze zahtevalo je detaljnu analizu strategija razvoja obrazovanja i informacionog društva od globalnog do nacionalnog nivoa, dok je testiranje dodatne hipoteze zahtevalo sprovođenje konkretnog istraživanja među studentima, putem ankete.

Rad je strukturiran $\mathrm{u}$ tri celine. Nakon uvodnih razmatranja o problematici kojoj je posvećeno ovo istraživanje, u prvom delu rada sagledana su različita viđenja budućnosti obrazovanja, kao i obrazovanja za budućnost, u kontekstu održivog ekonomskog razvoja. U drugom delu rada analizirani su načini i modeli uvođenja IKT u obrazovanje, u cilju pripremanja kadrova za njihovo korišćenje u poslovanju. Treći deo rada je usredsređen na Republiku Srbiju (RS) i bavi se sagledavanjem uticaja primene IKT u obrazovanju na razvojna dostignuća nacionalne ekonomije. U zaključnim razmatranjima, sumirani su rezultati istraživanja, koji se, pre svega, odnose na ukazivanje na značaj uvođenja IKT u obrazovne sisteme sa ciljem da se mladi ljudi što bolje pripreme za funkcionisanje $\mathrm{u}$ digitalizovanom poslovnom okruženju i daju svoj doprinos unapređivanju makroekonomskih i socijalnih performansi zemlje.

\section{BUDUĆNOST OBRAZOVANJA I OBRAZOVANJE ZA BUDUĆNOST U KONTEKSTU ODRŽIVOG EKONOMSKOG RAZVOJA}

Obrazovanju za budućnost pridaje se velika pažnja u strategijama razvoja od nacionalnog, pa do globalnog nivoa. Svetski lideri zemalja članica UN, njih 193, 
u septembru 2015, na Generalnoj skupštini UN, jednoglasno su usvojili Agendu održivog razvoja 20152030, usmerenu na ostvarivanje ekonomskog razvoja, koji je postojan i kvalitetan, zasnovan na zdravim ekonomskim temeljima, odgovornom odnosu prema prirodnom okruženju i zadovoljavanju kriterijuma socijalne pravde. To nije razvoj $u$ sadašnjosti na račun budućnosti, već razvoj koji zadovoljava potrebe tekućih generacija ne ugrožavajući sposobnost budućih naraštaja da podmiruju njihove vlastite potrebe (Mulamula \& Amadi-Echendu, 2017, 123). Pomenuta globalna razvojna agenda obuhvata 17 ciljeva, 169 podciljeva i 244 indikatora za merenje progresa. Sa stanovišta teme ovog rada, posebno je bitan cilj 4 - osigurati inkluzivno i kvalitetno obrazovanje za sve i promovisati celoživotno učenje, i u okviru njega podcilj 4.4. - do 2030. godine značajno povećati broj mladih i odraslih koji imaju relevantne veštine, uključujući tehničke i stručne veštine, za zapošljavanje, pristojne poslove i preduzetništvo (UN, 2015, 20).

Evropska unija je prepoznala značaj obrazovanja za budućnost i njegovu ulogu u ostvarivanju održivog razvoja, koji je prihvaćen kao univerzalni razvojni model na nivou ove regionalne integracije. Shodno tome, obrazovanje i obuka su dobili istaknuto mesto $\mathrm{u}$ strategiji EU za tekuću deceniju, pod nazivom Evropa 2020, koja se zalaže za: "pametan rast zasnovan na znanju i inovacijama; održiv rast usredsređen na promociju resursno efikasnije, zelenije i konkurentnije privrede i inkluzivan rast čija je glavna preokupacija izgradnja ekonomije sa visokom zaposlenošću, koja obezbeđuje ekonomsku, socijalnu i teritorijalnu koheziju" (EC, 2010, 8).

U strategijama Evropske unije, za podsticanje ekonomskog rasta, globalne konkurentnosti i kohezije društva, ključnu ulogu imaju visoko obrazovanje, nauka i inovacije. S obzirom na želju evropskih društava da postanu društva zasnovana na znanju, visoko obrazovanje je ključna komponenta društveno-ekonomskog razvoja i razvoja kulture. Porast potražnje za veštinama zahteva od visokog obrazovanja da na ove potrebe odgovori na nov način (EURASHE, 2015, 6).
Za razvoj visokog obrazovanja u Evropi značajnu ulogu ima Bolonjski proces. To je proces reforme visokog obrazovanja na nivou Evrope koji ima za cilj uspostavljanje Evropskog prostora visokog obrazovanja (European Higher Education Area - EHEA). Grupa za praćenje Bolonjskog procesa (Bologna Followup Group - BFUG), usvojila je 2014. Standarde i smernice za osiguravanje kvaliteta na Evropskom prostoru visokog obrazovanja (The Standards and guidelines for quality assurance in the European Higher Education Area - ESG), koje su 2015. usvojili i ministri EHEA. Ključni cilj ovih standarda je zajednički pristup osiguravanju kvaliteta za učenje i podučavanje od strane svih zemalja i sudeonika.

Širenje pristupa visokom obrazovanju, koji se ističe u svim ovim strategijama, prilika je da institucije visokog obrazovanja iskoriste sve raznovrsnija iskustva onih koji ih upisuju. Ta raznolikost i rastuća očekivanja od visokog obrazovanja zahtevaju sveobuhvatnu promenu $u$ načinu na koje se ono izvodi: "usmeravanje podučavanja i učenja na studente, prihvatanje fleksibilnih puteva učenja i priznavanje kompetencija stečenih izvan formalnih kurikuluma. Same visokoobrazovne institucije postaju sve raznolikije po misijama, vrstama obrazovanja i saradnje, što uključuje i porast internacionalizacije, digitalno učenje i nove oblike izvođenja nastave" (ENQA, 2015).

Prema izveštaju Izvršne agencije za obrazovanje, audiovizualnu delatnost i kulturu (Education, Audiovisual and Culture Executive Agency - EACEA), $\mathrm{u}$ 47 zemalja Evropskog prostora visokog obrazovanja, visoko obrazovanje pohađa oko 37,2 miliona studenata. Teorijske programe, akademske studije, upisalo je skoro $82 \%$ studenata, a samo $15,6 \%$ strukovne programe. Programe doktorskih studija pohađa 2,6\% studentske populacije (EACEA, 2015, 38).

Evropske institucije visokog obrazovanja dominatno se finansiraju iz javnih izvora. Preko polovine zemalja ulaže više od 1,3\% BDP-a u visoko obrazovanje, a među njima prednjače nordijske zemlje (od 2\% BDP-a u Švedskoj do 2,4\% BDP-a u Danskoj). Godišnja javna potrošnja na visoko obrazovanje najniža je i iznosi ispod 1\% BDP-a u Bugarskoj, Hrvatskoj, Italiji, Rumuniji i Slovačkoj (EACEA, 2015, 29-31). 
U istom izveštaju se navodi da je udeo mladih ljudi sa visokim obrazovanjem među nezaposlenima veoma nizak u Danskoj, Velikoj Britaniji, Holandiji, a u Nemačkoj ih čak nedostaje. S druge strane, mladi ljudi sa visokim obrazovanjem u Bosni i Hercegovini, Grčkoj, Hrvatskoj, Kipru, Portugaliji, Rumuniji i RS suočavaju se sa velikom nezaposlenošću.

Prema podacima Republičkog zavoda za statistiku (RZS) i Nacionalne službe za zapošljavanje (NSZ) u RS, mladi starosti od 15 do 29 godina čine $22 \%$ u odnosu na ukupan broj nezaposlenih (Slika 1). Nezaposlenost je jedan od razloga odlaska mladih, a posebno talenata.

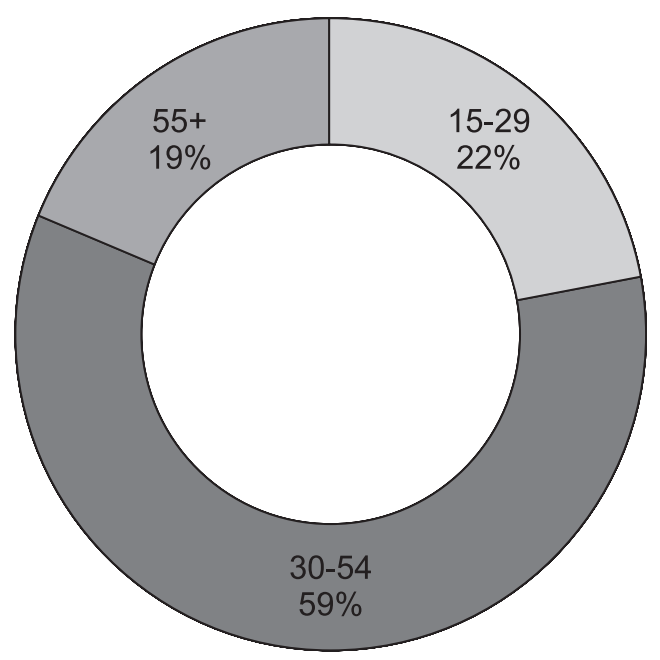

Slika 1 Učešće nezaposlenih prema starosnim grupama u ukupnom broju nezaposlenih, 2017.

Izvor: Nacionalni zavod za zapošljavenje (RZS - DevInfo, 2018, 3).

Shodno potrebama da svoj obrazovni sistem prilagodi savremenim zahtevima, a u skladu sa strategijama koje su prihvaćene $\mathrm{u}$ širem kontekstu, pre svega, imajući u vidu evropski prostor, Vlada RS je 2012. usvojila Strategiju razvoja obrazovanja u Srbiji do 2020. godine. Strategija se bavi utvrđivanjem svrhe, ciljeva, pravaca, instrumenata i mehanizama razvoja sistema obrazovanja u Republici Srbiji do 2020. godine. U Strategiji su posebno naglašena sledeća razvojna opredeljenja (Vlada RS, 2012):
- usmeravanje strukture obrazovnih i istraživačkih aktivnosti ka zadovoljenju razvojnih potreba privrede i društva;

- povećanje učešća populacije s visokim obrazovanjem u ukupnoj populaciji; i

- usmeravanje sistema finansiranja prema formiranju kreativnih, inovativnih, odgovornih visokoobrazovanih ljudi koji su neophodni da bi se ostvario ekonomski rast i smanjila nezaposlenost.

\section{INFORMACIONO-KOMUNIKACIONE TEHNOLOGIJE U OBRAZOVANJU}

IKT zahtevaju od nas drugačija znanja i veštine kako bismo iskoristili njihovu moć u privatnom i u poslovnom okruženju. Taj uticaj može se posmatrati u dva pravca, jedan koji iziskuje korišćenje IKT za unapređenje samog nastavnog procesa, a drugi, potrebu da se kroz obrazovni sistem nauči kako na najbolji način koristititi prednosti ovih tehnologija u različitim oblastima ljudske delatnosti, pa tako i u poslovanju.

Primenom IKT edukacija izlazi iz okvira tradicionalne nastave i postaje nezavisna od lokacije i vremena i često se naziva e-obrazovanje.

Pojam e-obrazovanje najčešće se definiše kao izvođenje aktivnosti vezane za obrazovni proces putem IKT ili kao elektronski potpomognuto učenje. E-obrazovanjem postižu se sledeći ciljevi: samostalno i permanentno učenje, viši nivo efikasnosti nastavnog procesa, fleksibilno organizovanje nastave i veći obuhvat onih koji žele i mogu da uče.

Neke od prednosti e-obrazovanja su: mogućnosti učestvovanja u edukaciji u bilo koje vreme i s bilo kojeg mesta; bolja interaktivnost profesora i studenata; ušteda vremena; veća efikasnost; fleksibilno učenje; individualni pristup studentima i prihvatanje različitih stilova učenja; individualno prilagođavanje sadržaja i tempa učenja; podsticanje studenata na analitičko mišljenje, sintetizovanje stečenih znanja i samostalno rešavanje problema, napredak u učenju može se lako proveravati i pratiti; jednostavnije 
stručno usavršavanje i prekvalifikacija; pružanje novih mogućnosti za celoživotno učenje; jednostavnije organizovanje predavanja svetskih stručnjaka putem videokonferencijskog prenosa; uključivanje raznih profila polaznika (zaposleni, studenti iz nedostupnih sredina, osobe s poteškoćama u kretanju, itd.).

Neke od savremenih tehnologija koje se primenjuju u e-obrazovanju su: pametna obrazovna okruženja, Internet inteligentni uređaji, virtuelno okruženje za učenje, tehnologije virtuelne realnosti, mobilne tehnologije itd.

Novu dimenziju učenju dodaje Virtuelno okruženje za učenje (Virtual Learning Environment - VLE), sistem koji pomoću IKT stvara ambijent dizajniran da olakša upravljanje obrazovnim kursevima. VLE uključuje i učenje na daljinu.

Posebno mesto $u$ obrazovanju nalaze i nove tehnologije, kao što su: Internet inteligentni uređaji (Internet of Things - IoT) i Cloud Computing stvarajući Pametna obrazovna okruženja. IoT je koncept koji proširuje virtuelni svet i Internet na fizičke stvari iz realnog sveta, omogućavajući virtuelizaciju resursa. Cloud Computing predstavlja tehnologiju koja omogućava interakciju između korisnika i različitih servisa koji su pristupačni na Internetu.

Moć Tehnologija virtuelne realnosti (Virtual Reality VR) se posebno ogleda u mogućnostima za iskustveno učenje kroz eksperimente koji studente mogu da nauče da rešavaju kompleksne probleme na drugačiji način u odnosu na tradicionalne obrazovne metode.

Korišćenje mobilnih tehnologija $u$ edukaciji predstavlja još jedan način da se transformiše učenje. Mobilne tehnologije mogu da imaju veliki značaj $\mathrm{u}$ razvoju sveprisutnog okruženja za učenje.

Uvažavajući potrebe obrazovnih sistema unutar EU, u dokumentu Otvaranje obrazovanja: inovativna nastava i učenje za sve kroz nove tehnologije i otvorene obrazovne resurse (Opening up Education: Innovative teaching and learning for all through new Technologies and Open Educational Resources), Evropska komisija ističe da su tehnologije i otvoreni obrazovni resursi prilika za preoblikovanje obrazovanja (EC, 2013).
U ovom dokumentu se utvrđuje evropski program podsticanja kvaliteta visokog obrazovanja, inovativnih načina učenja i podučavanja pomoću novih tehnologija i digitalnih sadržaja. Dokumentom Otvaranje obrazovanja, predlažu se mere za stvaranje otvorenijeg okruženja za učenje kako bi se osigurao visok kvalitet i efikasnost obrazovanja i na taj način doprinelo postizanju ciljeva iz strategije Evropa 2020, pre svega, vezanih za povećanje konkurentnosti EU pomoću kvalifikovanije radne snage i veće zaposlenosti. Glavni ciljevi su smanjenje stope ranog napuštanja školovanja i povećanje broja osoba sa završenim visokoškolskim obrazovanjem. Takođe, predložene su mere na nivou EU: pomaganje obrazovnim institucijama, nastavnicima, učenicima i studentima da usvoje digitalne veštine i metode učenja i podučavanja; podržavanje razvoja i dostupnosti otvorenih obrazovnih resursa; uvođenje digitalnih uređaja i sadržaja u učionice; mobilisanje svih zainteresiranih strana (nastavnika, učenika i studenata, porodica, preduzeća i socijalnih partnera), kako bi se promenila uloga digitalnih tehnologija $\mathrm{u}$ institucijama obrazovanja (EC, 2013).

Nove tehnologije $\mathrm{u}$ visokom obrazovanju doprinose stvaranju kadrovskog potencijala koji je neophodan za ostvarivanje najznačajnijih ekonomskih efekata razvoja IKT sektora (Kvochko, 2013): rast BDP-a; pojava novih usluga i industrija; poslovne inovacije; transformacija radne snage; otvaranje novih radnih mesta. Zbog toga je u dokumentu Strategija razvoja obrazovanja u Srbiji do 2020. godine jedan od postavljenih ciljeva usaglašavanje studijskih programa i stručne prakse s potrebama privrede, kako bi studenti stekli što više znanja, veština i kompetencija koje su relevantne potrebama poslodavaca (Vlada RS, 2012).

U Strategiji razvoja obrazovanja u Srbiji do 2020. godine naglašava se značaj digitalnih tehnologija za celokupan razvoj sistema obrazovanja. Međutim, prvi zvanični dokument, koji se na sveobuhvatan način bavi integracijom digitalnog $\mathrm{i}$ online učenja $\mathrm{u}$ sistem obrazovanja, doneo je Nacionalni prosvetni savet tokom 2013. kada su javnosti predstavljene Smernice za unapređivanje uloge informacionokomunikacionih tehnologija u obrazovanju. 


\section{IKT U OBRAZOVANJU KAO PODSTICAJ EKONOMSKOM RASTU I RAZVOJU REPUBLIKE SRBIJE}

IKT su već više godina centralna tema u diskusijama o ekonomskom rastu i funkcionisanju ekonomija razvijenih zemalja, ali i nerazvijenih zemalja i zemalja u razvoju.

Šira primena IKT u obrazovanju i podizanje nivoa znanja i veština za korišćenje novih tehnologija, kod najšire populacije, prepoznati su od strane države kao značajan pokretač razvoja ekonomije i društva RS.

Najvažniji ciljevi koje treba postići potpunijom primenom IKT u obrazovanju u RS, određeni su Strategijom razvoja informacionog društva do 2020. godine. Reč je o sledećim ciljevima: uspostavljanje modernog obrazovnog sistema koji je prilagođen potrebama informacionog društva; osposobljenost za primenu IKT na radnom mestu na način kojim se podiže stepen efikasnosti, poboljšava kvalitet rada i obezbeđuju bolji poslovi; i uvođenje savremenog koncepta e-učenja i otvorenog učenja na daljinu.

Za ostvarivanje određenih društvenih i ekonomskih koncepata neophodne su kompetencije. Ove kompetencije se formiraju reformisanjem sektora obrazovanja, kako bi se stvorili preduslovi za izgradnju ekonomije znanja, kao i podsticanjem treninga i obuka za korišćenje IKT. Iz tih razloga su neophodne promene $\mathrm{u}$ obrazovanju kako bi se osavremenio proces učenja i podstakli kretivnost i inovacije. Povezivanjem IKT sektora i obrazovanja pomoćiće mladima da steknu veštine koje su im potrebne da se pripreme za digitalno radno okruženje.

Stanje IKT sektora u RS prikazano je u nastavku analize.

Prema podacima RZS i Privredne komore Srbije PKS (PKS, 2017), u 2015, u IKT sektoru, poslovalo je 3.401 privredno društvo, što čini 3,7\% ukupnog broja registrovanih privrednih društava u RS. Od toga, najviše je registrovanih privrednih društava u oblasti računarskog programiranja $(54,9 \%)$, potom u oblasti proizvodnje računara, elektronskih i optičkih uređaja $(26,8 \%)$ i telekomunikacija $(11,5 \%)$.
Kao što se može videti u Tabeli 1 , mikro i mala preduzeća činila su 97\% registrovanih privrednih društava, a najveći promet ostvarila su velika privredna društva. Takođe, vidi se da je najveći broj zaposlen $u$ velikim i srednjim privrednim društvima (Tabela 1).

Tabela 1 Struktura privrednih društava u delatnostima elektronskih komunikacija i informacionog društva - 2015.

\begin{tabular}{l|ccccc}
\hline & Ukupno & $\begin{array}{c}\text { Mikro } \\
1-9\end{array}$ & $\begin{array}{c}\text { Malo } \\
10-49\end{array}$ & $\begin{array}{c}\text { Srednje } \\
50-249\end{array}$ & $\begin{array}{c}\text { Veliko } \\
250+\end{array}$ \\
\hline $\begin{array}{l}\text { Privredna } \\
\text { društva }\end{array}$ & 3.401 & $85.6 \%$ & 11,4 & 2,4 & 0,6 \\
Zaposlenost & 55.159 & $10,5 \%$ & 14,1 & 15,5 & 59,8 \\
$\begin{array}{l}\text { Ostvareni } \\
\text { promet } \\
\text { (u mld RSD) }\end{array}$ & 418,9 & $7,8 \%$ & 14,2 & 21,4 & 56,6 \\
\hline
\end{tabular}

Izvor: RZS i APR, preračun PKS.

U 2016, u IKT sektoru bilo je registrovano 61.077 zaposlenih, što je za 2,5\% više u odnosu na 2015. Značajno povećanje registrovane zaposlenosti u odnosu na period januar-decembar 2015. zabeleženo je u oblasti računarskog programiranja, konsultantskih i s tim povezanih delatnosti, za 23,9\% (PKS, 2017).

U periodu januar-mart 2017, u okviru IKT sektora najveća isplaćena bruto zarada iznosila je 205.259 dinara u delatnosti računarsko programiranje, konsultantske i s tim povezane delatnosti, što je oko tri puta više u odnosu na republički prosek (62.588 dinara) (PKS, 2017).

Prema podacima RZS i PKS (PKS, 2017), u 2015, registrovan je pozitivan doprinos svih delatnosti vezanih za IKT sektor međugodišnjem rastu BDP-a. Značajan međugodišnji rast bruto dodate vrednosti registrovan je $\mathrm{u}$ delatnostima računarskog programiranja i konsultantskih delatnosti (25,3\%) i informacionih uslužnih delatnosti (27,9\%). Bruto dodata vrednost ostvarena $u$ delatnosti računarskog programiranja, konsultantskih i s tim povezanih delatnosti u 2015. godini, iznosila je 402,2 miliona evra. Ukupne realizovane investicije u osnovne 
fondove svih delatnosti koje su vezane za IKT su 2015. godine iznosile 476,8 miliona evra, od čega je najveći deo od 225,3 miliona evra bio usmeren u domaću i uvoznu opremu (47,3\%) i oko 41,8\% u intelektualnu svojinu (istraživanje i razvoj, softveri, baze podataka i ostalo) u vrednosti od 199,2 miliona evra. U okviru delatnosti računarskog programiranja, konsultantskih i s tim povezanih delatnosti gotovo $69,2 \%$ investicija bilo je usmereno u istraživanje i razvoj, softvere i baze podataka.

Prema podacima Narodne banke Srbije (NBS) i PKS (PKS, 2017), tokom 2016, u privrednim granama koje obuhvataju elektronske komunikacije i informaciono društvo, ostvaren je neto priliv stranih direktnih investicija, po osnovu ulaganja nerezidenata, od 100,2 miliona evra. U trogodišnjem periodu, od 2014. do 2016, ostvaren je prosečan godišnji rast neto priliva stranih direktnih investicija od 70,1\%.

U 2016. je, prema podacima NBS i PKS (PKS, 2017), od izvoza telekomunikacionih, kompjuterskih i informacionih usluga ostvareno je 739,5 miliona evra prihoda. U četvorogodišnjem periodu, od 2013. do 2016, ovaj izvoz rastao je po prosečnoj stopi od 19,2\% godišnje. U razmeni ovih usluga ostvaren je suficit u vrednosti 407,3 miliona evra. Suficit u razmeni ovih usluga je u četvorogodišnjem periodu 2013-2016, rastao po prosečnoj stopi od 36,9\% godišnje, pri čemu je najveći rast suficita u razmeni kompjuterskih usluga $(43,2 \%)$.

Na osnovu podataka koji su prezentovani, nameće se zaključak da je IKT sektor u RS, iako ga čini 3,7\% ukupnog broja registrovanih privrednih društava i 3,2\% zaposlenih u RS, u 2016. ostvario izvoz od 739,5 miliona evra, a u razmeni usluga iz ovog sektora ostvaren je suficit u vrednosti 407,3 miliona evra. Takođe, u RS, koju odlikuje visoka nezaposlenost, zanimanja vezana za IKT spadaju u retka kod kojih je veća ponuda poslova od interesovanja kandidata.

Na globalnom nivou, IKT sektor predstavlja jednu od najbrže rastućih industrija, koja direktno utiče na otvaranje velikog broja radnih mesta i podstiče razvoj drugih sektora privrede. Savremena preduzeća, da bi bila konkurentna na globalnom tržištu, moraju da, uz što niže troškove, primene najnovije tehnologije. To je i dovelo do prenosa ovih tehnologija iz ekonomski najrazvijenih zemalja $u$ Indiju, Kinu i druge zemlje Azije, koje imaju dobro obučenu i jeftinu visokokvalifikovanu radnu snagu. Ovi trendovi usmereni su i ka RS, koja ima određen, mada nedovoljan, broj visokoobrazovanih kadrova za primenu IKT u poslovanju (Bartlett, 2009, 33).

Iz prethodne analize, vidljivo je da računarsko programiranje i pružanje različitih informatičkih usluga postaju sve značajniji faktori ekonomskog razvoja RS. IT zanimanja spadaju u najtraženija na tržištu radne snage. Dakle, značajan je potencijal koji IT industrija RS pruža mladim talentovanim i visokoobrazovanim ljudima da svoje karijere grade u RS i budu zadovoljni i svojim statusom i mogućnošću da doprinesu prosperitetu svoje zemlje. Međutim, postoje i značajni nedostaci koji karakterišu IKT industriju u Srbiji, a to su: veliki broj mikro preduzeća koja imaju niske finansijske kapacitete i nedovoljne tehnološke i upravljačke veštine i nedostatak kvalitetnog stručnog kadra.

Ovim nedostacima treba dodati još jedan, veoma važan, a to je da ne uspevamo da zadržimo talente $u$ zemlji, jer je RS, po podacima Svetskog ekonomskog foruma, po kapacitetu za zadržavanje talenata na 134. mestu od 137 država (WEF, 2017, 257).

Međutim, treba imati u vidu da zaključak da treba ulagati u obrazovanje ljudi i da će se ta ulaganja vratiti kroz ubrzani privredni rast, važi samo pod pretpostavkom da će ljudi dobiti posao i time priliku da daju svoj doprinos ekonomskom razvoju. Pozitivna iskustva nekih zemalja govore da je, umesto usmeravanja na celu privredu $\mathrm{u}$ jednom trenutku, bolje da se zemlje fokusiraju na one sektore koji mogu da obezbede siguran napredak, kao, na primer, IKT sektora u RS, a to za sobom povlači i potrebu prilagođavanja visokoobrazovnog sistema $u$ tom pravcu.

\section{FORMALNO OBRAZOVANJE U OBLASTI IKT U REPUBLICI SRBIJI}

U nižim razredima osnovnih škola, od prvog do četvrtog, postoji izborni predmet Od igračke do 
računara. Za učenike petih razreda osnovnih škola u RS, od septembra 2017, uveden je predmet Informatika i računarstvo u obaveznu nastavu, a koji će ubuduće imati učenici šestih, sedmih i osmih razreda $u$ osnovnom obrazovanju.

U gimnazijama se od prvog do četvrtog razreda, i u srednjim stručnim školama u prvom razredu, izučava predmet Računarstvo i informatika. U srednjim stručnim školama u drugom, trećem i četvrtom razredu postoje informatički predmeti prilagođeni određenom području. U školama iz područja rada Ekonomija, pravo i administracija, izučava se predmet Poslovna informatika.

Okosnicu visokog obrazovanja, istraživanja i razvoja u oblasti IKT predstavljaju tehnički i matematički fakulteti. Ovi fakulteti se fokusiraju na inženjersku informatiku, dok nedostaju studijski programi posvećeni poslovnoj informatici.

Razlog slabe ponude studijskih programa iz poslovne informatike, naročito na državnim fakultetima, može se naći $u$ tome što su $u$ RS informatičari inženjeri prepoznati kao IT stručnjaci, dok su poslovni informatičari nedovoljno afirmisani. Ipak, mogu se uočiti promene $u$ tom pogledu, pre svega, kroz zahteve poslodavaca za znanjima koja njihovi zaposleni u oblasti informatike treba da imaju. Naime, poslovna komponenta $\mathrm{u}$ informatici je sve traženija, što se može zaključiti iz analize oglasa na jednom od vodećih sajtova za zapošljavanje u RS - Poslovi infostud. Od ukupnog broja ponuđenih IT radnih mesta, koji se kreće oko 300, približno 200 se odnosi na ona radna mesta za koja se traže kompetencije koje bi posle diplomiranja trebalo da poseduju studenti koji podjednako dobro poznaju IKT i određenu oblast poslovanja (Infostud, 2018).

Trenutno na tržištu radne snage $u$ RS nema dovoljne ponude ekonomski obrazovanih informatičara, usmerenih ka poslovnoj primeni informacionih tehnologija, izradi poslovnog software-a, upravljanju IT projektima i razvoju poslovnih informacionih sistema. Faktori koji su doprineli povećanoj tražnji ovih kadrova su:
- u poslednjih nekoliko godina u RS je značajno uvećan broj domaćih i, naročito, međunarodnih IT kompanija koje se bave razvojem poslovnog software-a, što pruža mogućnost da IT stručnjaci mogu iz RS da rade za kompanije iz čitavog sveta;

- kvalitetni visokoobrazovni programi iz oblasti poslovne informatike mogli bi značajno da unaprede našu software-sku industriju;

- povećanje interesovanja kandidata za upis na fakultete za sticanjem znanja i veština koji povezuju ekonomiju i informacione tehnologije, a da po završetku fakulteta imaju veoma izvesnu mogućnost zapošljavanja.

Rukovodeći se podacima koji su izneti i u ovom radu o potrebama tržišta radne snage $u$ RS, a u cilju dobijanja informacija o zainteresovanosti studenata da se više usmere ka predmetima koji povezuju IKT i ekonomiju, anketirani su studenti koji pohađaju prvu godinu na Ekonomskom fakultetu, Univerziteta u Beogradu. U anketi je učestvovalo 535 studenata. Anketa je obuhvatala širi broj pitanja, a za ovaj rad odabrana su pitanja koja se odnose na predmete koji povezuju IKT i ekonomiju.

Analiza zainteresovanosti studenata za pojedine predmete koji su usmereni ka primeni IKT $u$ poslovanju, a koji su predviđeni u okviru modula Poslovna informatika (Poslovna informatika, Baze podataka, Analiza podataka, Objektno orijentisano programiranje, Matematičke osnove računarstva, Web dizajn, Informacioni sistemi i poslovna analitika, Elektronsko poslovanje, Razvoj software-a, Menadžment IT projekata, ERP software, Nove informacione tehnologije, Elektronska trgovina, Elektronski platni sistemi, Digitalni marketing i Računovodstveni informacioni sistem) pokazuje da su studenti posebno zainteresovani za sledeće predmete: Digitalni marketing - 63,6\% anketiranih studenata, Elektronsku trgovinu - 60,9\%, Web dizajn - 60\%, Elektronsko poslovanje - 54,9\%, Menadžment IT projekata - 51,6\%, Elektronski platni sistem - 49,6\%, Nove informacione tehnologije - 47,1\% anketiranih studenata. Detalji zainteresovanosti studenata za ove predmete mogu se videti u sledećim tabelama (Tabele 2 - 8). 
Tabela 2 Nivo zainteresovanosti studenata za Web dizajn

\begin{tabular}{|c|c|c|c|c|c|}
\hline & & Broj & $\%$ & $\begin{array}{l}\text { \% validnih } \\
\text { odgovora }\end{array}$ & $\begin{array}{c}\% \\
\text { ukupno }\end{array}$ \\
\hline \multirow{6}{*}{ 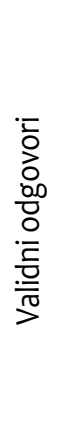 } & Nezainteresovan & 45 & 8,4 & 8,6 & 8,6 \\
\hline & $\begin{array}{c}\text { Slabo } \\
\text { zainteresovan }\end{array}$ & 50 & 9,3 & 9,6 & 18,2 \\
\hline & $\begin{array}{c}\text { Umereno } \\
\text { zainteresovan }\end{array}$ & 106 & 19,8 & 20,3 & 38,5 \\
\hline & Zainteresovan & 130 & 24,3 & 24,9 & 63,4 \\
\hline & $\begin{array}{c}\text { Veoma } \\
\text { zainteresovan }\end{array}$ & 191 & 35,7 & 36.6 & 100,0 \\
\hline & Ukupno & 522 & 97,6 & 100,0 & \\
\hline \multicolumn{2}{|c|}{ Nedostajući podaci } & 13 & 2,4 & & \\
\hline \multicolumn{2}{|r|}{ Ukupno } & 535 & 100,0 & & \\
\hline
\end{tabular}

Izvor: Autori

Tabela 3 Nivo zainteresovanosti studenata za elektronsko poslovanje

\begin{tabular}{|c|c|c|c|c|c|}
\hline & & Broj & $\%$ & $\begin{array}{l}\text { \% validnih } \\
\text { odgovora }\end{array}$ & $\begin{array}{c}\% \\
\text { ukupno }\end{array}$ \\
\hline \multirow{6}{*}{ 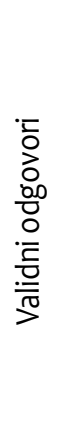 } & Nezainteresovan & 39 & 7,3 & 7,4 & 7,4 \\
\hline & $\begin{array}{c}\text { Slabo } \\
\text { zainteresovan }\end{array}$ & 53 & 9,9 & 10,1 & 17,5 \\
\hline & $\begin{array}{c}\text { Umereno } \\
\text { zainteresovan }\end{array}$ & 139 & 26,0 & 26,5 & 44,0 \\
\hline & Zainteresovan & 158 & 29,5 & 30,1 & 74,1 \\
\hline & $\begin{array}{c}\text { Veoma } \\
\text { zainteresovan }\end{array}$ & 136 & 25,4 & 25,9 & 100,0 \\
\hline & Ukupno & 525 & 98,1 & 100,0 & \\
\hline \multicolumn{2}{|c|}{ Nedostajući podaci } & 10 & 1,9 & & \\
\hline \multicolumn{2}{|r|}{ Ukupno } & 535 & 100,0 & & \\
\hline
\end{tabular}

Izvor: Autori
Tabela 4 Nivo zainteresovanosti studenata za objektno orijentisano programiranje

\begin{tabular}{|c|c|c|c|c|c|}
\hline & & Broj & $\%$ & $\begin{array}{l}\text { \% validnih } \\
\text { odgovora }\end{array}$ & $\begin{array}{c}\% \\
\text { ukupno }\end{array}$ \\
\hline \multirow{6}{*}{ 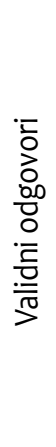 } & Nezainteresovan & 133 & 24,9 & 25,4 & 25,4 \\
\hline & $\begin{array}{c}\text { Slabo } \\
\text { zainteresovan }\end{array}$ & 131 & 24,5 & 25,0 & 50,5 \\
\hline & $\begin{array}{c}\text { Umereno } \\
\text { zainteresovan }\end{array}$ & 120 & 22,4 & 22,9 & 73,4 \\
\hline & Zainteresovan & 87 & 16,3 & 16,6 & 90,1 \\
\hline & $\begin{array}{c}\text { Veoma } \\
\text { zainteresovan }\end{array}$ & 52 & 9,7 & 9,9 & 100,0 \\
\hline & Ukupno & 523 & 97,8 & 100,0 & \\
\hline \multicolumn{2}{|c|}{ Nedostajući podaci } & 12 & 2,2 & & \\
\hline \multicolumn{2}{|r|}{ Ukupno } & 535 & 100,0 & & \\
\hline
\end{tabular}

Izvor: Autori

Tabela 5 Nivo zainteresovanosti studenata za razvoj software-a

\begin{tabular}{|c|c|c|c|c|c|}
\hline & & Broj & $\%$ & $\begin{array}{l}\text { \% validnih } \\
\text { odgovora }\end{array}$ & $\begin{array}{c}\% \\
\text { ukupno }\end{array}$ \\
\hline \multirow{6}{*}{ 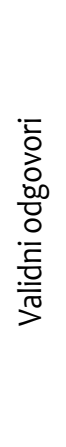 } & Nezainteresovan & 130 & 24,3 & 25,0 & 25,0 \\
\hline & $\begin{array}{c}\text { Slabo } \\
\text { zainteresovan }\end{array}$ & 118 & 22,1 & 22,7 & 47,7 \\
\hline & $\begin{array}{c}\text { Umereno } \\
\text { zainteresovan }\end{array}$ & 123 & 23,0 & 23,7 & 71,3 \\
\hline & Zainteresovan & 93 & 17,4 & 17,9 & 89,2 \\
\hline & $\begin{array}{c}\text { Veoma } \\
\text { zainteresovan }\end{array}$ & 56 & 10,5 & 10,8 & 100,0 \\
\hline & Ukupno & 520 & 97,2 & 100,0 & \\
\hline \multicolumn{2}{|c|}{ Nedostajući podaci } & 15 & 2,8 & & \\
\hline \multicolumn{2}{|r|}{ Ukupno } & 535 & 100,0 & & \\
\hline
\end{tabular}

Izvor: Autori 
Tabela 6 Nivo zainteresovanosti studenata za nove informacione tehnologije

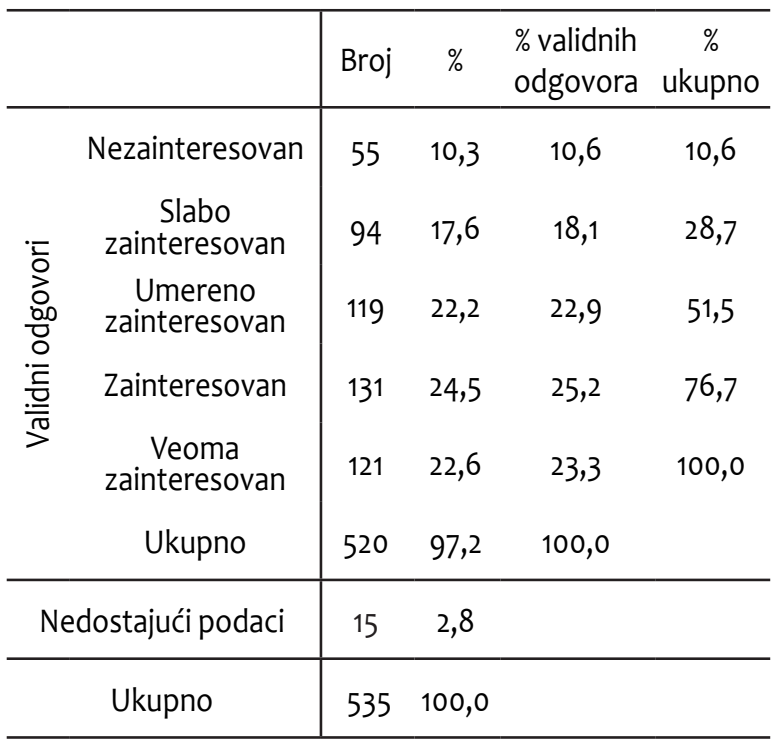

Izvor: Autori

Tabela 7 Nivo zainteresovanosti studenata za elektronsku trgovinu

\begin{tabular}{|c|c|c|c|c|c|}
\hline & & Broj & $\%$ & $\begin{array}{l}\text { \% validnih } \\
\text { odgovora }\end{array}$ & $\begin{array}{c}\% \\
\text { ukupno }\end{array}$ \\
\hline & Nezainteresovan & 31 & 5,8 & 5,9 & 5,9 \\
\hline & $\begin{array}{c}\text { Slabo } \\
\text { zainteresovan }\end{array}$ & 49 & 9,2 & 9,4 & 15,3 \\
\hline 吾 & $\begin{array}{c}\text { Umereno } \\
\text { zainteresovan }\end{array}$ & 118 & 22,1 & 22,5 & 37,8 \\
\hline 흠 & Zainteresovan & 161 & 30,1 & 30,7 & 68,5 \\
\hline & $\begin{array}{c}\text { Veoma } \\
\text { zainteresovan }\end{array}$ & 165 & 30,8 & 31.5 & 100,0 \\
\hline & Ukupno & 524 & 97,9 & 100,0 & \\
\hline & edostajući podaci & 11 & 2,1 & & \\
\hline & Ukupno & 535 & 100,0 & & \\
\hline
\end{tabular}

Izvor: Autori
Tabela 8 Nivo zainteresovanosti studenata za digitalni marketing

\begin{tabular}{|c|c|c|c|c|c|}
\hline & Broj & $\%$ & $\begin{array}{l}\text { \% validnih } \\
\text { odgovora }\end{array}$ & $\begin{array}{c}\% \\
\text { ukupno }\end{array}$ \\
\hline \multirow{6}{*}{ 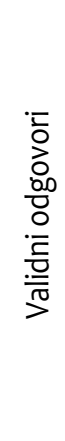 } & Nezainteresovan & 33 & 6,2 & 6,3 & 6,3 \\
\hline & $\begin{array}{c}\text { Slabo } \\
\text { zainteresovan }\end{array}$ & 48 & 9,0 & 9,2 & 15,5 \\
\hline & $\begin{array}{c}\text { Umereno } \\
\text { zainteresovan }\end{array}$ & 102 & 19,1 & 19,5 & 35,0 \\
\hline & Zainteresovan & 138 & 25,8 & 26,4 & 61,4 \\
\hline & $\begin{array}{c}\text { Veoma } \\
\text { zainteresovan }\end{array}$ & 202 & 37,8 & 38.6 & 100,0 \\
\hline & Ukupno & 523 & 97,8 & 100,0 & \\
\hline \multicolumn{2}{|c|}{ Nedostajući podaci } & 12 & 2,2 & & \\
\hline & Ukupno & 535 & 100,0 & & \\
\hline
\end{tabular}

Izvor: Autori

Kao što pokazuju rezultati ove ankete, studenti su posebno zainteresovani za ekonomski orijentisane informatičke predmete, odnosno, za predmete koji $\mathrm{su}$ fokusirani na primenu IKT $\mathrm{u}$ određenoj oblasti poslovanja.

\section{ZAKLJUČAK}

$\mathrm{U}$ radu se ukazuje na ključnu ulogu kvalitetnog $\mathrm{i}$ inkluzivnog obrazovanja za ostvarivanje dinamičnog i održivog ekonomskog razvoja i skiciraju poželjni pravci promena u skladu sa zahtevima novog doba.

Ulaganje $\mathrm{u}$ obrazovanje je investicija $\mathrm{u}$ budućnost. Globalni trend je da nove tehnologije snažno deluju na svet rada i obrazovanje. Promene se manifestuju kroz pojavu novih kategorija poslova i zanimanja, koji će delimično, ili u potpunosti zameniti postojeće. Potrebna znanja i veštine će se, takođe, bitno menjati. $\mathrm{Na}$ izazove novog doba se mora brzo reagovati kako bi se izbegli ogromni ekonomski i socijalni troškovi za pojedince, preduzeća i privredu. U radu se skreće pažnja na to da novi talas tehnoloških 
promena otvara neslućene mogućnosti zemljama širom sveta, uključujući i manje razvijene, da kroz transformaciju sistema obrazovanja značajno poboljšaju svoje performanse na ekonomskom i širem društvenom planu. U tom kontekstu, obrazovanje se prepoznaje kao razvojna šansa RS. Tome govore u prilog rezultati predstavljenih istraživanja, kao i neophodnost sprovođenja promena, koje se kreću od tretmana obrazovanja u društvu, preko reformi u samom obrazovnom sistemu, pa sve do izgradnje odgovarajućih ekonomskih, pravnih i političkih institucija, kako bi se motivisali mladi da stiču znanje i povećao kapacitet zemlje da zadrži i privuče najkvalitetnije kadrove.

U radu je ukazano da je neophodno integrisanje novih tehnologija u sve aspekte obrazovnog procesa, sa ciljem efektivnijeg i efikasnijeg obrazovanja. Veštine vezane za nove tehnologije odlučujuće su za konkurentnost nacionalne ekonomije i povećanje mogućnosti za nova radna mesta.

Takođe, neophodne su promene u školama, univerzitetima i drugim organizacijama koje se bave obrazovanjem, kako bi se, boljim korišćenjem mogućnosti koje pružaju nove tehnologije, osavremenio proces učenja i podstakli kretivnost i inovacije. Uvođenje novih tehnologija $u$ obrazovne procese treba da omogući da visokoobrazovani mladi ljudi, sa adekvatnim znanjima i veštinama, koristeći najnovije tehnologije, doprinesu razvoju ekonomije svoje zemlje.

Ovaj rad je prilog analizi posrednog uticaja primene novih IKT u obrazovanju na ekonomski rast i razvoj, što je i njegov ključni naučni i praktični doprinos, naročito kada se ima u vidu nedostatak radova i istraživanja tog uticaja u svoj njegovoj kompleksnosti.

Sistematska analiza strategija razvoja obrazovanja i razvoja informacionog društva, od globalnog nivoa (UN), Evropske unije, Republike Srbije, pa do analize konkretnog kurikuluma na Ekonomskom fakultetu, Univerziteta u Beogradu, sprovedena u ovom radu, potvrdila je osnovnu hipotezu da je neophodno integrisanje IKT u sve aspekte obrazovnog procesa, sa ciljem efektivnijeg i efikasnijeg obrazovanja.
Detaljna analiza IKT sektora i tržišta radne snage $\mathrm{u}$ RS, uz korišćenje podataka relevantnih institucija (RZS, NBS, PKS, NZS itd.), i podataka iz sprovedene ankete, potvrdila je i dodatnu hipotezu o povećanom interesovanju mladih ljudi da steknu znanja i veštine za digitalizovano radno okruženje i da daju svoj doprinos ekonomskom rastu i razvoju zemlje.

Prikazana istraživanja $\mathrm{u}$ radu $\mathrm{u}$ dobroj meri daju odgovor na pitanje kako IKT u obrazovanju podstiču ekonomski rast i razvoj. Međutim, ostaje otvoreno pitanje, relevantno za buduća istraživanja, koje se odnosi na merenje tog uticaja, odnosno, koliko IKT u obrazovanju podstiču ekonomski rast i razvoj. Takođe, preciznijoj analizi zainteresovanosti studenata za primenu IKT u ekonomiji, doprinelo bi šire istraživanje, po uzoru na anketu sprovedenu na Ekonomskom fakultetu, Univerziteta u Beogradu, koje bi obuhvatilo više visokobrazovnih institucija $u$ Republici Srbiji.

\section{ZAHVALNICA}

Ovaj rad je deo projekata osnovnih istraživanja (br. 179005, 179065 i III-46001), koje finansira Ministarstvo prosvete, nauke i tehnološkog razvoja Republike Srbije.

\section{REFERENCE}

Bartlett, W. (2009). Economic development in the European super-periphery: Evidence from the Western Balkans. Economic Annals, 64(181), 21-44. doi:10.2298/EKA0981021B

EACEA (Education, Audiovisual and Culture Executive Agency). (2015). The European Higher Education Area in 2015. Brussels, Belgium.

EC - European Commission. (2010). Europe 2020 - A Strategy for smart, sustainable and inclusive growth. Brussels: COM(2010) 2020 final. Retrieved March 24, 2018, from ec.europa.eu/ eu2020/pdf

EC - European Commission. (2013). Opening up Education: Innovative teaching and learning for all through new Technologies and Open Educational Resources. Brussels, Belgium. 
EC - European Commission. (2014). Digital Agenda for Europe. Brussels, Belgium.

EC - European Commission. (2016). A New Skills Agenda for Europe. Brussels, Belgium.

EC - European Commission. (2017). National Student Fee and Support Systems in European Higher Education, 2017/18. Brussels, Belgium.

Education Commission. (2017). The Learning Generation - Investing in education for a changing world. Retrieved December 13, 2017, from report.educationcommission.org

ENQA - European Association for Quality Assurance in Higher Education. (2015). Standards and Guidelines for Quality Assurance in the European Higher Education Area. Brussels, Belgium.

EURASHE - European Association of Institutions in Higher Education. (2015). Standards and Guidelines for Quality Assurance in the European Higher Education Area (ESG). Brussels, Belgium.

Hanushek, E., \& Woessmann, L. (2008). The role of cognitive skills in economic development. Journal of Economic Literature, 46(3), 607-678. doi:10.1257/jel.46.3.607

Infostud. (2018). Poslovi Infostud.

Kvochko, E. (2013). Five ways technology can help the economy. World Economic Forum.

Laskowska, I., \& Dańska-Borsiak, B. (2016). The Importance of human capital for the economic development of EU regions. Comparative Economic Research, 19(5): 63-79. doi. org/10.1515/cer-2016-0038

McCowan, T. (2016). Universities and the post-2015 development agenda: An analytical framework. Higher Education, 72(4), 505-523. doi:10.1007/s10734-016-0035-7

Mulamula, G., \& Amadi-Echendu, J. (2017). An examination of the potential links between ICT technology transfer and sustainable development. International Journal of Technology Management \& Sustainable Development, 16(2), 119-139. doi:10.1386/tmsd.16.2.119_1
NPS - Nacionalni prosvetni savet Srbije. (2013). Smernice za unapređenje uloge informaciono-komunikacionih tehnologija $u$ poslovanju.

PKS - Privredna komora Srbije. (2017). Bilten, april 2017. Udruženje za elektronske komunikacije i informaciono društvo.

RZS - Republički zavod za statistiku DevInfo. (2018) Republika Srbija - profil. Retrieved March 11, 2018, from http://devinfo. stat.gov.rs

Schwab, K. (2016). Fourth Industrial Revolution. Geneva, Svis: World Economic Forum.

Vlada Republike Srbije. (2010). Strategija razvoja informacionog društva u Srbiji do 2020. godine. Službeni glasnik RS, br. 51/2010.

Vlada Republike Srbije. (2012). Strategija razvoja obrazovanja u Srbiji do 2020. godine. Službeni glasnik RS, br. 107/2012.

Todaro, M. P., \& Smith, C. S. (2011). Economic Development. Harlow: Addison-Wesley.

UN. (2012). The Future We Want. Geneva, United Nations: Retrieved March 14, 2018, from http:// sustainabledevelopment.un.org/content/documents/ 733FutureWeWant.pdf

UN. (2015). Transforming Our World: the 2030 Agenda for Sustainable Development. Geneva: United Nations.

UNESCO. (2016). Global Education Monitoring Report - Education for People and Planet: Creating Sustainable Futures for All. Paris, France: UNESCO.

WEF - World Economic Forum. (2011). The Global Information Technology Report 2010-2011.

WEF - World Economic Forum. (2017). The Global Information Technology Report 2016.

Primljeno 16. marta 2018, nakon revizije, prihvaćeno za publikovanje 23. aprila 2018. Elektronska verzija objavljena 26. aprila 2018. 
Rade Stankić je redovni profesor Ekonomskog fakulteta Univerziteta u Beogradu. Predmet njegovog naučnog interesovanja je vezan za teme iz oblasti poslovne informatike i poslovnih informacionih sistema.

Biljana Jovanović Gavrilovićje redovni profesor Ekonomskog fakulteta Univerziteta u Beogradu. Predmet njenog naučnog interesovanja je vezan za teme iz oblasti nacionalne ekonomije.

Jasna Soldić Aleksić je redovni profesor Ekonomskog fakulteta Univerziteta u Beogradu. Predmet njenog naučnog interesovanja je vezan za teme iz oblasti analize podataka i poslovnih informacionih sistema.

\title{
INFORMATION AND COMMUNICATION TECHNOLOGIES IN EDUCATION AS A STIMULUS TO ECONOMIC DEVELOPMENT
}

\author{
Rade Stankic, Biljana Jovanovic Gavrilovic and Jasna Soldic Aleksic \\ Faculty of Economics, University of Belgrade, Belgrade, The Republic of Serbia
}

Education has always been a driving force behind economic prosperity. However, this has become especially important in a globalized knowledge- and new-technology-based economy. The research presented in this paper focuses on the relationship between ICT, population education, and economic growth and development. The analysis of this relationship is based on the latest data collected from relevant national and international institutions. The results obtained from a survey conducted at the Faculty of Economics, University of Belgrade, are also analyzed. The paper highlights the challenges faced by the education systems in general, and the education system of Serbia in particular, confronted with the new wave of technological innovation which is fundamentally changing the nature of work and imposing new requirements with regard to the necessary knowledge and skills. Our research results indicate that ICT and education have been recognized by the Government of Serbia as the important determinants of economic and the overall social development.

Keywords: information and communication technologies (ICT), education, economic growth, economic development

JEL Classification: O14, M15, L63 